\title{
Preaching to the Choir? \\ Rhetoric and Identity in a Polarized Age
}

\author{
Rob Goodman, Ryerson University \\ Samuel Bagg, University of Oxford
}

NB: This is the final pre-publication version of an article that is now published in the Journal of Politics. Please cite the published version. Email me for a copy, or if you have access through your institution, you can download it here: doi.org/10.1086/715171

\begin{abstract}
How might discourse generate political change? So far, democratic theorists have focused largely on how deliberative exchanges might shift political opinion. Responding to empirical research that casts doubt on the generalizability of deliberative mechanisms outside of carefully designed forums, this essay seeks to broaden the scope of discourse theory by considering speech that addresses participants' identities instead. More specifically, we ask what may be learned about identity-oriented discourse by examining the practice of religious preaching. As we demonstrate, scholars of homiletics - the study of preaching-have identified three core features that support its focus on identity: its unconditionality, its appeal to authoritative texts and traditions, and its diffuse instrumentality. We then ask what each of these features might look like in more straightforwardly political contexts. Finally, we address several normative questions raised by this practice, as a way of exploring the promises and dangers accompanying identity-oriented discourse more generally.
\end{abstract}

Key words: deliberation; homiletics; identity; preaching; rhetoric 


\section{Introduction}

What leads people to change their minds about politics? This is surely a crucial matter for those who seek to achieve political change through the nonviolent means of democratic discussion. Yet democratic theorists have given it surprisingly scant attention. Deliberative democrats and their critics alike have focused primarily on deciding which kinds of political speech are normatively acceptable on their own terms, and have been somewhat less concerned to discover which kinds of speech are actually effective at achieving political transformations.

Unfortunately, the understanding of political behavior that has emerged from recent studies of public opinion and political psychology casts doubt on the model of discourse-driven political change that is often taken for granted in these discussions. Even among those who have sought to transcend the narrow focus of early deliberative theorists on the pure exchange of reasons, there remains an almost exclusive emphasis on the mechanism of changing opinions through discursive exchanges of some kind. Yet if we accept the extensive empirical evidence that our political engagement is always profoundly shaped by our underlying social identities, we have good reason to believe that the impact of this mechanism will remain quite limited. Whatever their intrinsic value, that is, deliberative reasoning and other forms of opinion-oriented discourse will only rarely bring about the kind of political transformations at which they ostensibly aim.

In this essay, we seek to further broaden the discourse about discourse in democratic theory, considering speech that directly addresses participants' identities rather than their opinions. Of course, we cannot canvass all varieties of identity-oriented discourse, nor consider all available perspectives on it. We certainly cannot claim to present a comprehensive answer to the question of what leads people to change their minds about politics. Instead, our aim is to stimulate further inquiry into these topics by turning to a particularly salient example of identity-oriented discourse, 
which already has a well-developed scholarly tradition devoted to it. That example is religious preaching, and the study of it is known as "homiletics." In brief, then, this essay asks what can be learned about identity-oriented discourse from the discipline of homiletics.

We begin with the mismatch between deliberative aspirations and empirical evidence. By focusing almost entirely on processes of opinion change, we surmise, deliberative theorists neglect potentially more impactful discourses oriented directly towards listeners' identities. We turn next to the modern academic discipline of homiletics - at least, in this essay's limited focus, as it has developed in largely American and Protestant circles - which identifies three key characteristics of preaching as supporting its orientation to identity: its unconditionality, its appeal to authoritative texts and traditions, and its diffuse instrumentality. We then ask what each of these discursive techniques might look like in more straightforwardly political contexts. Finally, we explore the promises and dangers of preaching in politics — and of identity-oriented discourse more broadly.

Like nearly all political strategies, we conclude, political preaching can be used for good or ill, and deserves neither to be celebrated nor demonized categorically. As such, our focus on it should not be misconstrued as advocacy for it. What we do insist, however, is that democratic theorists must grapple more seriously with the crucial role of identity in political discourse, and this essay represents a contribution to that much broader project. In examining the accounts of preaching developed by scholars of homiletics, we hope to advance our understanding of how political actors already make use of identity-oriented discourse - and how they might do so more democratically.

\section{Persuasion, conversion, and mobilization: three modes of discursive change}

Let us begin by considering the idealized model of discourse found in early (or "first-wave") deliberative theory (e.g., Benhabib 1996; Cohen 1997; Habermas 1996). On this model, citizens come together on roughly equal terms to address questions of shared concern, motivated solely by 
the desire to achieve the common good, or at least to resolve conflicts fairly. Though they may disagree strongly at first, each gives arguments in good faith, and listens to fellow citizens do the same. As a result, we can expect some to change their beliefs and preferences-i.e., their opinions.

On the whole, deliberative theorists suppose, these changes will be progressive and convergent. The process may never yield consensus, but groups who deliberate in good faith, under the right conditions, should begin to approach a shared sense of the common good, or at least a fair procedure for resolving any remaining disagreements. Rather than just aggregating the unreflective opinions of each individual, the deliberative process subjects those opinions to scrutiny, eventually weeding out unsupported beliefs and weak arguments. Absent distortions from hierarchy and prejudice, indeed, they will eventually gravitate towards the best answer-inexorably drawn, in Habermas's iconic phrase, by the "unforced force of the better argument."

Everyone knows that deliberation rarely (if ever) works like this in practice. But deliberative theorists claim that this idealized model of "the transformation of preferences through rational discussion" (Elster 1986, 104) is useful—or perhaps even necessary-as an aspiration. More precisely, it can help us identify and remedy the pathologies which, they acknowledge, will inevitably afflict any real deliberation. Though discourse is never entirely free of distortions, after all, some contexts do approximate the exchange of reasons on equal terms better than others.

Still, the political implications of this model are limited. We cannot assume, for instance, that everyone deliberates sincerely or comes to the table on equal terms (Knight and Johnson 1997). Relatedly, those with greater fluency in "reasonable" communicative forms will have an advantage (Sanders 1997; Young 2001). As a result, following norms suitable for ideal circumstances within the nonideal world will often yield counterproductive results, which are generated not by the 
"unforced force" of the better argument but by pre-existing power relations (Shapiro 1999). Worse, these power relations may gain greater force and finality by wearing the mask of neutral reason.

In response, "second-wave" deliberative theorists have suggested several modifications to deliberative theory. Some have expanded the admissible registers of democratic discourse, aiming to be more inclusive (Allen 2004; Garsten 2006; Young 2000). Meanwhile, others have allowed that even explicitly non-deliberative action will on occasion be necessary (Fung 2005; Mansbridge et al. 2010, Lepoutre 2019). These are welcome interventions. Crucially for our purposes, however, such second-wave deliberative theories retain a focus on opinions. ${ }^{1}$ The primary end of discourse, in other words, is still to change participants' political views in a convergent, progressive direction. If a relevant fact is discussed, the expectation is that people will update their beliefs. If a novel argument is raised, the expectation is that people will re-evaluate the overall balance of concerns. In short, deliberative rhetoric drives political change by shaping participants' beliefs and preferences, which are then assumed to change their behavior. We call this process persuasion.

Persuasion does happen in the real world. Especially in politics, however, it is rarer than we might expect. A great deal of research in public opinion and political psychology—building on foundational work in social psychology (Brewer 1991; Tajfel 1982) and cognitive science (Kunda 1990; Lodge and Taber 2013) — has converged on what we call the "social identity" model of political behavior (Achen and Bartels 2016; Green, Palmquist, and Schickler 2002; Greene 1999; Huddy 2001; Iyengar, Sood, and Lelkes 2012; Mason 2018). And unfortunately for the practical ambitions of deliberative democracy, this model casts doubt on the transformative potential of persuasive rhetoric and other forms of opinion-oriented discourse.

\footnotetext{
${ }^{1}$ As Garsten writes, for instance, "the persuasion involved in deliberation will involve deferring to certain opinions even as it aims to change others" (Garsten 2006, 198).
} 
Broadly speaking, proponents of this model understand social identity in terms of "the social categories, attributes, or components of the self-concept that are shared with others" (Monroe, Hankin, and Vechten 2000, 421; see also Tajfel 1978). Everyone has multiple social identities, on this view, but the most salient categories vary widely across time and space. In the United States, for instance, party identification and race have long been understood as crucial for motivating political behavior, but in other contexts, other affiliations - such as class, religion, ethnicity, or gender - might be more prominent. People may also identify with groups based on regional background, occupation, union membership, or any other trait they have in common with others.

The key finding of social identity theory, then, is that our political engagement is profoundly shaped, from beginning to end, by whichever group identities we find most salient. In our initial perception of political reality, we engage in "identity-protective cognition"-interpreting the world "in a manner that buttresses beliefs associated with belonging to particular groups" (Kahan et al. 2007, 470). The same processes of "motivated reasoning" then have a pervasive influence on our internal reflection and deliberation with others as well (Nyhan and Reifler 2010; Strickler 2018; Taber and Lodge 2006). Finally, social identity also plays a crucial role in explaining the forms of political action we take (Huddy, Mason, and Aarøe 2015; Klandermans 2014). Indeed, observed political behavior can diverge quite substantially from self-reported beliefs, preferences, and ideological orientation, and in such cases, group identification is often a better predictor. Even when our behavior appears to match our opinions, meanwhile, there are good reasons to think that social identity is still the driving causal force behind this correlation (Barber and Pope 2019).

To the extent that we are interested in achieving political change, then, it seems likely that opinion-oriented persuasion will be of limited use. Studies have shown that under certain conditions and on certain issues, deliberation can change people's minds-by helping them 
overcome factual deficits, for instance, or discover mutually beneficial compromises (Goodin and Niemeyer 2003; Luskin, Fishkin, and Jowell 2002). Yet these favorable deliberative conditions are hard to create outside of small-scale experiments, and even within such conditions, opinions about more salient political issues are more resistant to change (Bächtiger et al. 2007). When fundamental questions of power and morality are at stake, there is likely to be a stronger connection to identity (Bartels 2002), and the scope of opinion-oriented persuasion will be narrower. So while the possibility of opinion-oriented persuasion leading to changes in underlying identity cannot be ruled out, existing research suggests that such instances will be rare.

What is the alternative? Clearly, there are many ways of pursuing political change which do not center on deliberative reason or persuasive rhetoric. Even remaining within the realm of discourse, however, the foregoing arguments suggest a more promising approach. If the impact of deliberative rhetoric is limited by its orientation to the opinions of its intended audience — which are best seen as an outgrowth of underlying group identities - then perhaps a more effective form of discourse would target these identities more directly. That is the possibility we take up here.

More specifically, we discuss two distinct processes whereby identities are shifted through discursive interaction. The first and perhaps more familiar is what we call conversion, whereby someone is induced to abandon an old identity or embrace a new one. The second is a looser set of processes we call mobilization, whereby the implications of a given identity are shifted, or the relative motivational force of various identities is altered. Following Teresa Bejan (2015), we may refer to the identity-oriented discourse that initiates both processes as "evangelizing" discourse, in order to distinguish it from the opinion-oriented "deliberative" rhetoric that generates persuasion.

Two clarifications must be made immediately. First, those engaged in these processes-either as speakers or as listeners - may not understand them in the terms of conversion, mobilization, or 
evangelism, and in some cases may strenuously object to the connotations of these terms. ${ }^{2}$ Indeed, some may find the language of "identity" inappropriate to the religious context we begin with. We fully acknowledge that we are imposing these categories of analysis from the outside, based on standard norms in social science research, and we eschew any claim to present a comprehensive or authoritative account of these processes. Nevertheless, we do contend that our categories are useful for answering the particular questions about discursive political change we have posed.

Second, no hard lines can be drawn between these categories. In practice, rather, persuasion, conversion, and mobilization are inextricably linked and overlapping processes. At times, for instance, significant opinion changes induced by persuasion may shade into processes of identity change that look more like conversion or mobilization. Still, we believe that these categories are empirically distinctive enough to warrant separate analysis. More importantly, the distinction between persuasion and these other categories tracks an important lacuna in deliberative theory, which has generally de-emphasized the role of identity (vis-à-vis opinion) in processes of discourse-driven political change (though see Burke 1969, Phillips 1995, Young 2000).

Given that evangelizing discourse can easily be used for ill, we might think that this exclusive focus on deliberative reason is justified. As second-wave deliberative theorists have insisted, however, the same can be said of deliberative rhetoric and reason-giving: no form of discourse is entirely trustworthy. Conversely, evangelizing discourse is not necessarily anti-democratic (Bejan 2017). As we address below, it can be dangerous, and should not be universally endorsed. But neither can it be universally rejected. Given the tight connection between identity and opinion,

2 To some critics, for instance, seeking to "evangelize" or "convert" listeners betrays an undemocratic or "imperialist" attitude. In our expansive terms, however, conversion occurs whenever discourse leads to significant shifts in a participant's identity — even if it is experienced as "care" or "liberation" - while mobilization includes processes that might better be described as "organizing" or "solidarity-building." 
those of us hoping to achieve political change through discursive engagement cannot rest our hopes entirely on the mechanism of persuasion: we must also confront the promises and dangers of conversion and mobilization. Rather than seeing such shifts in identity as mere quantitative extensions of opinion changes, moreover, we must identify their distinctive qualitative features, as well as the distinctive styles of rhetoric that might set them in motion. Despite the vast literature on discourse in democratic theory, very little work has been devoted to these topics.

There is, however, a discipline that has considered such issues in a systematic way: homiletics, or the study of preaching. As we show in the next section, homileticians have often conceived of preaching in terms of its capacity to shape identities, and have developed a considerable body of thought on the means of doing so. They have also developed a compelling account of what distinguishes identity-oriented preaching, which aims at conversion or mobilization, from opinionoriented deliberative rhetoric, which aims at persuasion. We turn to examine this account now.

\section{Preaching and identity formation: insights from homiletics}

The category of preaching is tremendously broad - encompassing a wide range of religious traditions, settings, and forms. For many religious leaders and thinkers, for instance, the activity of "preaching" is hardly limited to the pulpit, and in fact may take place largely outside the realm of discourse altogether. Even if we limit ourselves to explicitly discursive forms of preaching, there are as many ways to conceive of our subject matter as there are traditions of religious speech. Indeed, it is somewhat artificial to consider "religious" discourse as a distinct category to begin with: the idea of separating life into religious and secular spheres is an historical anomaly associated primarily with Western modernity (Asad 2003; Mahmood 2015).

As such, we do not claim to give a comprehensive account of all forms of preaching or religious discourse. Instead, our scope is confined to a particular tradition of homiletic scholarship, largely 
Protestant in theology, and largely situated in American divinity schools - and even here, our treatment is inevitably incomplete. In particular, the variety of discursive practices employed by preachers educated in this tradition surely exceeds the limits of the homiletic imagination. Simply put, preachers cannot be expected to consistently do as professional homileticians say. Further, the practice of preaching is shaped not only by homiletic theory, but by power relations within religious institutions (see Lincoln 2006, 7). Yet despite its limitations as a guide to the lived reality of preaching, we believe that examining the homiletic tradition has distinct value. Given the dearth of attention devoted to identity-oriented discourse-especially relative to its political importance—its insights may still significantly advance our understanding.

We also recognize that the relationship between religious preaching and non-religious forms of deliberative or persuasive rhetoric is complex, especially in a Christian tradition shaped by the interaction of Greco-Roman and Hebrew sources (see Zulick 2011). Many scholars emphasize the continuities between preaching and the tradition of classical rhetoric. In De doctrina christiana, for instance, Augustine recommended that preachers study classical rhetoric, defended the Hebrew and Greek scriptures as models of eloquence, and treated preaching as the faithful appropriation of techniques initially developed for worldly use (Enos and Thompson 2008). More recently, George Kinneavy (1987) has explored the roots of the Greek scriptures' concept of faith in Greek rhetorical theory's concept of belief or proof, all of which are indicated by the word pistis. And Frank A. Thomas $(2016,62)$ argues that "African American preaching is inherently and naturally rhetorical," refusing to recognize a sharp distinction between its rhetorical and theological aspects.

Yet others treat homiletic concepts as qualitatively different from their rhetorical counterparts. Such scholars highlight the contrast between the preacher's activity of textual interpretation and the activity of invention that forms the basis of rhetoric. Similarly, they emphasize the differences 
between the preacher's moral authority, which is usually thought to extend beyond the sermon, and the orator's ethos, which in the Aristotelian account is seen as inherent in the speech itself (Kennedy 1999, 133, 150). In some views, indeed, the preacher is seen less as an independent persuader than as a medium through which grace acts, or does not act, on the listener. As the Reformed theologian Karl Barth put it, a prompt to conversion or decision "may well happen in a sermon, of course, but they are acts which God himself wills to perform and which can never, therefore, be a human task" (1991 [1932-33], 48; see Miller 1939, 300-330).

Without presuming to resolve this dispute, we draw from both tendencies. In discussing the ways in which preaching can serve as a model for discourse-driven political change, and in setting aside Barth's theological view of the source of preaching's efficacy, we draw from scholars highlighting the continuities between preaching and secular rhetoric. But in arguing that preaching remains qualitatively distinct from deliberative forms of rhetoric aimed primarily at persuasion, we draw from those emphasizing the discontinuities. And in the latter respect, homileticians often point to a sharper focus on identity as one of the key aspects that set preaching apart.

It is this address to identity, for instance, that allows homileticians to distinguish a text that is commented on from a scripture that is preached on. Text becomes scripture, writes David Kelsey (1975, 91, emphasis in original), when 'it functions to shape persons' identities so decisively as to transform them." Similarly, Henry H. Mitchell (1997, 379, emphasis in original), observes that preaching on scripture is often "occupied with the task of building identification. We want the hearer to identify with the protagonist," and to respond, “"That's my story."” Thomas Long (2005, 106) adds that the preacher's goal "is neither the plucking of an abstract idea from the text nor some nonconceptual aesthetic experience but, rather, the event of the text's actively shaping self and communal understanding." Preaching presumes that our identities are malleable. In what 
follows, then, we highlight three features of preaching discourse that homileticians have identified as especially conducive to shifts in identity. Each of these features, we argue, contributes to the qualitative distinction between preaching and deliberative rhetoric.

The first of these is what we call "unconditionality," referring to the limits on the preacher's accommodation to listeners' existing commitments. Just like deliberative orators, of course, many preachers do aim to appeal to their audiences - a task made easier by the homogeneity of religious institutions even in relatively diverse places like the United States (Margolis 2018, 6). In practice, both preachers and orators navigate between two extremes: one in which the message is so tailored to the audience's existing views as to be identical to them, and another in which the message is so alien to the audience's existing views that it essentially passes unheard. Yet unlike deliberative orators, preachers are ultimately committed to announcing the truth of scripture, regardless of who hears it. As such, homiletics is friendlier to the latter extreme than the tradition of classical rhetoric.

According to historian of rhetoric George Kennedy $(1999,123)$, for instance, the scriptural passages taken to authorize Christian preaching practices assume that "disciples cannot expect to persuade their judges of the righteousness of their cause; that is God's work." As he notes, this contravenes "the assumptions of the classical orator, who is expected to use his eloquence to overcome opposition." Indeed, the word for "preach" frequently used in these passages is kêrusso - literally, "proclaim"- suggesting the activity of a herald rather than an orator (123; see Fry Brown 2003, 17).

The homiletician Fred Craddock (1985, 43-4) draws on similar sources in arguing that, in principle (if not always in practice), preachers should not distinguish between receptive and unreceptive listeners:

There is a non-contingent, unconditional quality to the word we preach; it does not wait for a favorable response....According to Luke 10:1-16, Jesus instructs seventy 
and sends them out two by two. According to Jesus' instructions, the word to those who received the messengers was, "The kingdom of God has come near." To those who rejected the messengers, the word was, "The kingdom of God has come near." There is a "regardless of the response" integrity to the message; one does not wait to check the climate of the audience in order to discover what to say.

In the tradition of deliberative rhetoric, by contrast, speaking the same words to diametrically opposed audiences is a flagrant sin. Accordingly, this refusal to "engage with others wherever they stand and to begin our argument there" (Garsten 2006, 3) is perhaps preaching's sharpest divergence from that tradition. But because preaching presumes the malleability of identity, it presumes at the same time that distinctions in identity - the same distinctions that serve to justify the rhetorician's flexibility of address — are less real than they might appear.

Homileticians do not claim that preachers are or ought to be totally indifferent to the needs and concerns of their audiences. Nevertheless, the homiletic ideal of unconditionality holds that preachers must not assign listeners to fixed categories of receptivity and non-receptivity. As David Buttrick writes, a preacher's audience "must be regarded as being-saved in the world," meaning that the categories of "saved" and "worldly" should not be understood as permanent. A concept of preaching is deficient if it presumes fixity_by aiming exclusively at either "switching people from unfaith to faith" (akin to what we call "conversion") or "explication of common faith" (comparable to "mobilization"), for instance, or even by treating these as distinct activities $(1987,40-1)$.

Conforming to the homiletic ideal of unconditionality, then, does not doom preachers to repeating themselves endlessly, regardless of the audience, or to offering exactly the same message as others in their tradition. Yet those who conceive of their speech in terms of "proclamation" will be less concerned to seek out a rhetorical "point of contact" with their audiences than those who conceive of their speech in terms of persuasion. One need not endorse Barth's theological claim that ensuring the effectiveness of preaching "can never...be a human task" to believe that those 
who see their work in such terms are less likely to be concerned with the prospect of immediate success than those who presume no such mediation between the speaker's words and the listener' reaction: success, on this view of preaching, is ultimately out of the preacher's hands.

A second distinctive feature of preaching, on the homiletic account, is its reliance on an authoritative text or tradition. Preachers have frequently grounded their claims to influence in their role as expositor of a text or tradition that listeners already consider authoritative, or at least culturally prestigious. But if this relationship to scripture is a source of the preacher's authority, it also places a certain check on the preacher's freedom of action. Richard Lischer $(1988,69)$ argues that responsibility to the word, rather than to any particular anthropology, distinguishes preaching from secular rhetoric. Barth (1991 [1932-33], 115) cautions preachers against "confus[ing] the beautiful thoughts of our self-seeking ego with thoughts of the text, which are usually less comfortable." And in his retirement sermon, Gardner C. Taylor, the "dean of American preaching" and a leading figure in the civil rights movement, asked for forgiveness "if I ever tried to make the Word of God mean what I wanted it to mean" (quoted in Gilbert 2011, 114). We might say that scripture grants the preacher authority on a strictly constrained set of conditions. On the negative side of these injunctions, the preacher can be conceived as a mere "witness" to the text; on the positive side, determining through exegesis what one has witnessed and determining the form of words that will best bear witness to that discovery are both creative acts (Long 2005, 109).

To be sure, deliberative rhetoric also draws upon accepted sources of authority. As such, this feature of preaching is less distinctive than the others. Yet there are also important differences in approach. One might say that deliberative rhetoric makes an internal appeal, attempting to justify new beliefs or preferences as coherent with those the audience already holds. And to some extent, preaching shares this standpoint: the preacher must know which texts and traditions the audience 
already considers authoritative. In this way, indeed, this feature of preaching stands in some tension with the ideal of unconditionality. On the other hand, however, this knowledge eventually becomes the basis of an external appeal: an appeal ultimately grounded not in the existing views of the audience, but in an authority conceived as standing outside both audience and speaker.

Either way, it is this link to accepted authority that gives preaching much of its identity-shaping power. "It is the familiar, what is already known, that stabs and indicts," argues Craddock (1985, 46). In other words, the familiarity of a text can serve as a powerful source of cognitive dissonance, which preaching aims to both provoke and resolve. The same might be said for the familiarity of preaching itself: unlike deliberative rhetoric, which occurs in response to situations requiring judgment, preaching is iterated, repeated on a relatively predictable schedule. But the scripture the preacher expounds is familiar in the sense of "holding an acknowledged claim on the listener," not in the sense of "comfortable." Indeed, it is scripture's familiar discomfort that has often enabled it to serve as a source of "counter-imagination" and political resistance (Brueggemann 1993, 18).

One of the preacher's central dilemmas, then, is how to imbue a familiar and reiterated text with a sense of urgency. This challenge has been especially felt in homiletical debates on sermon form. If the goal is to "actively shap[e] self and communal understanding," it is not enough that listeners simply accede in a conclusion about what the text means. It is with that thought in mind that Craddock and others developed an influential account of "inductive" sermon form. On this account, as Long summarizes it, sermons should aim to recreate the "process of creative discovery employed by preachers in their exegetical work... so that the listeners can share the preacher's experience of illumination." Yet Long cautions against treating any sermon form as normative: sermons organized around narrative or "problem-solving," for instance, can also serve to recreate 
"the process of the discovery and experience of the gospel." Indeed, treating discovery itself as the normative experience is problematic in its own right $(2005,125,129-30)$.

In all of these forms, however, listeners' experience of the word is treated as primary. This suggests a third noteworthy feature of preaching — particularly emphasized by the New Homiletic movement that began in 1970s (Thomas 2016, 54)—which we call "diffuse instrumentality." On the traditional Aristotelian account of deliberative rhetoric, the orator speaks in order to prompt a particular judgment, action, or shift in opinion. A persuasive speech, Aristotle advises, ought to conclude with lines to the effect of, "The facts are before you. I ask for your judgment." On this model, therefore, orators must care about listeners' experience just to the extent that it serves the judgment she asks them to make. For Aristotle, emotions, in the context of rhetoric, are simply "those feelings that so change men as to affect their judgments" (1984, 1420b, 1378a).

Preaching has its own goals, to be sure, but they are often more diffuse. Preachers may aim to induce experiences of repentance, or gratitude, or cathartic "celebration," for instance - the last of which is especially important in Black homiletics (Gilbert 2011, 3; Mitchell 1990; Thomas 2016, 86) — without always aiming to produce specific behaviors. As Mitchell $(1973,338)$ writes, "preaching must be an experience, not merely a clever idea. It involves the totality of a person and is, consciously or not, concerned to organize feeling tones around the text." Similarly, Anna Carter Florence $(2007,135)$ contrasts quick and focused acts of decision-making-“forms of closure [that] serve human needs and desires"-with the patient process of "attending" to a sacred text. The changes in self-conception that such experiences are intended to bring about are more difficult to monitor than discrete behaviors, but they may also turn out to be deeper and longer-lasting.

This feature also has consequences for the characteristic style of preaching, which tends to be heavily image-laden. Deliberative rhetoric also makes use of metaphor, of course, but on Buttrick's 
account, imagery plays a more freestanding and impressionistic role in preaching, comparable to "the clusters of images in a poem, forming in consciousness along with a meaningful structure." For Buttrick, indeed, illustrations and images "all but preach a sermon" in their own right (1987, 163). Along the same lines, Lischer highlights how Martin Luther King Jr. used metaphor and metonymy to convey otherwise imperceptible moral ideals. In King's sermons, imagery "posits the real presence of moral values in the material world," such that "the mass confusion, brutality, and politics surrounding the march to the Edmund Pettus Bridge in Selma may actually point toward or 'stand for' the eternal quest for freedom" (Lischer 1995, 124). As such, preaching often sounds at odds with ordinary discourse. Preaching, as Kenyatta Gilbert $(2016,59)$ puts it, often sets out "to negate the dominant imagination through image and metaphor," in part because the dominant imagination can embody the relations of social power to which preaching may stand opposed. Finally, as Donna Allen $(2013,31)$ argues in her discussion of womanist homiletics, imagery in preaching may extend beyond the purely verbal, to the "creative use of gestures, dance and movement to act out or embody the sermon."

Perhaps the most powerful resource preaching has for shaping listeners' individual and collective sense of themselves is its use of longstanding, flexible, and capacious narrative tropes, such as slavery-exodus, creation-fall-redemption, or the pattern of promise-betrayal-restoration in the tradition of the jeremiad (Bercovitch 1978; Murphy 2009). Preaching is often narrative. But more to the point, it aims to places listeners inside a narrative that the preacher indicates and expounds, "locating our storied lives within a framework of beginning and end." These frameworks constitute our "narrative identity" (Buttrick, 1987, 13), and may profoundly shape the judgments we make throughout our lives (Thiele 2006). 


\section{The homiletic model in politics}

Armed with this homiletic account of the distinctive features of preaching as a form of identityoriented discourse, we turn now to imagine what it might look like to adopt this model in more straightforwardly political contexts. In doing so, we abstract away from its explicitly religious character. Yet as we have noted, the strict division of life into religious and secular realms familiar to citizens of many modern states is hardly natural or universal. And though many modern preachers accept this boundary, many others take the modes of discourse characteristic of preaching with them into the explicitly political realm. Just as preachers will often diverge from homiletic ideals in practice, finally, speakers without homiletic training or religious intent may unintentionally employ the distinctive discursive features of preaching.

How, then, do these distinctive features play out in political contexts? Here, we build on the contrast between preaching and deliberative rhetoric developed above, arguing that they can be understood not only as two distinct modes of speech, but as two broader orientations to political transformation. Taking each distinctive feature of preaching in turn, more specifically, we ask what it would look like to use that technique in politics — and how doing so would entail a departure from the rhetorical orientation. We then examine Frederick Douglass's renowned Fourth of July oration as an illustration of how all three features - unconditionality, authoritative texts and traditions, and diffuse instrumentality—can be successfully integrated in a political speech.

First, what does unconditionality mean in the context of politics? On the homiletic account summarized in the previous section, preaching is less prone than rhetoric to seek out a "point of contact" with audiences' existing views, or to sort listeners into fixed categories of "receptive" and "non-receptive," "saved" and "damned." In politics, this approach might lead one to address diverse audiences - including disaffected or even hostile audiences - in the same way and with 
roughly the same message, regardless of whether they appear likely to agree. The preaching approach thus runs afoul of the rhetorical tradition's first rule for effective communication: i.e., that the persuader must modulate his or her appeal to the audience as he or she finds it.

As an example of the rhetorical orientation, we might look to the triangulating approach of certain center-left, "third way" politicians of the late $20^{\text {th }}$ century. Consider, for instance, one of Tony Blair's New Labour slogans in the United Kingdom: "tough on crime, tough on the causes of crime." The slogan presumes that much of the audience approaches the issue of crime through the framework of "toughness" (e.g., incarceration, increased policing); "toughness" represents Blair's point of contact with the audience. In order to move listeners to the desired conclusionincreased attention to the social determinants of crime, such as poverty-the slogan represents it as simply another instance of the "toughness" that the audience is already primed to endorse.

Such an approach can be markedly effective: after all, it likely contributed to New Labour's landslide 1997 general election victory. Yet critics will argue that it is effective only with respect to a limited set of goals. In exchange for its evident persuasive success, Blair's slogan seems to ratify the view that "toughness" is the correct frame within which to address crime, and gives up any more radical attempt to realign the politics of crime around a different frame.

A rhetorical orientation may also place a premium on distinguishing "persuadables" from "unpersuadables," and on identifying the precise terms in which they are likely to be persuaded. Though Blair's slogan was widely deployed, the approach it represents is consistent with microtargeting and other practices of "quantified persuasion" (Kreiss 2017) in which distinct audiences receive narrowly tailored messages. Just as Blair's slogan takes the "toughness" frame for granted, microtargeting "reflects and reinforces...the clash of competing social groups, interests and values" by directing appeals towards "identity-congruent audiences" (Kreiss 2017). 
In other words, it takes existing configurations of identity for granted. Such an approach can thus contribute to political "redlining" (Howard 2006, 132), in which the most disaffected groups, because they are deemed the least persuadable, are largely excluded from political outreach.

This aspect of the rhetorical orientation to political change stands in sharp contrast with the preaching model. Compared to the triangulating Blair, for instance, certain polarizing figures of both the left and the right may come much closer to the homiletic ideal of unconditionality, in that they are much less willing to give ground to listeners' existing views. Barry Goldwater's 1964 campaign for the U.S. presidency, for instance, embodied his conviction that "extremism in the defense of liberty is no vice." Though it ended in a landslide defeat, it is widely credited with sowing the seeds for the conservative realignment brought to fruition by Ronald Reagan in 1980 .

More recently, Bernie Sanders sought to effect a similarly dramatic realignment on the left, aiming to consolidate plurality support within the Democratic party while winning over disaffected and first-time voters. Notably, Sanders offered nearly identical messages to favorable and potentially hostile audiences - including, controversially, on the sets of Fox News and Joe Rogan's podcast - and his reputation for ideological consistency became a key part of his political persona.

Sanders was ultimately less successful at building support within his party, of course, and there were many other ideological and strategic differences between the two candidates. Nevertheless, they shared a similar orientation to political change. For both, the point was less to secure immediate victories than to change the terms of politics in a more lasting way. As such, both were known for their tendency to simply "proclaim" their vision—much to the chagrin of partisan allies - even when doing so may have threatened their electoral prospects. And in both cases, a major part of their strategy was the promotion of political identities that were relative outliers in 
the context of American politics: i.e., movement conservative and democratic socialist, respectively.

Second, what does the appeal to authoritative texts and traditions mean in the context of politics? As with scripture in religious preaching, certain lodestars are widely accepted as having some claim on listeners' allegiance: the U.S. Declaration of Independence, for instance, or the traditions and tropes of French republicanism. Political appeals organized around such authorities often take the form of calling listeners "back" to the terms of a covenant, even when the politics at stake are decidedly new. Appeals to these authorities can therefore both enable transformative discourse and constrain the speakers. On the one hand, those who interpret such texts and traditions effectively can make powerful claims on their audiences. On the other hand, even the most creative interpreters are limited by the materials at hand, and by competition from rival interpretations.

Consider Abraham Lincoln's 1860 Cooper Union Address, for instance, which sets out to prove that a majority of the Constitution's signatories accepted the principle that the federal government could limit the spread of slavery. Lincoln begins by quoting a sentence spoken by his erstwhile opponent, Stephen Douglas - “Our fathers, when they framed the Government under which we live, understood this question just as well, and even better, than we do now" —and announces that he will "adopt it as a text for this discourse" (1953 [1860], 523). In other words, Lincoln consciously (if ironically) imitates the form of a sermon, and he proceeds to offer a detailed exegesis of the founders' views on slavery, referring back to "our fathers" 19 times.

In this case, there is less of a sharp contrast to be drawn with the rhetorical orientation: as noted in the previous section, deliberative rhetoric also relies on commonly accepted sources of value to build persuasive arguments. Yet note that the figures Lincoln appeals to here have a special status in American culture, such that their authority can be conceived as external to both himself and the 
audience. As we explored above, this is distinct from the internal appeals typical of traditional deliberative rhetoric, which treat the views of the audience themselves as the final authority.

Third, what does diffuse instrumentality mean in the context of politics? Preaching may have instrumental goals, we have argued, but in comparison to those of deliberative rhetoric, these goals are less immediate and well-defined. This follows naturally from its focus on shifting or mobilizing the audience's identity rather than on changing specific opinions or encouraging particular actions, and is associated with a longer time horizon, as well. Preaching may not be the most direct method of inducing immediate opinion change, but this does not necessarily make it less impactful over the long term. Even with the most powerful forms of deliberative rhetoric aimed at persuasion, discrete opinion changes are also exceedingly difficult to achieve-precisely because opinions are so tightly linked to identity. If preaching can change and mobilize identities, therefore-even if the process is slow and difficult to measure-it may prove a transformative political force.

Rather than trying to persuade an audience to make a specific judgment, political discourse modeled on preaching is designed to induce broader and deeper shifts of identity. As a result, it may de-emphasize immediate measures of success, while adopting distinctive discursive forms and styles. Rather than driving towards a particular judgment, it may strive to create a particular kind of experience - perhaps one whose implicit lessons are polyvalent or mysterious. If it issues any recommendations at all, these may be very general: more like an orientation towards the world than a policy platform. It may be especially dependent on imagery and metaphor, or upon placing people within a vivid narrative about the trajectory of their political community.

Sometimes, of course, narrowly and diffusely instrumental approaches may be combined — as, for instance, in Martin Luther King Jr.'s speech at the 1963 March on Washington. On one hand, the rally was explicitly framed as a march "for jobs and freedom," and King's speech was followed 
by the reading of a list of demands, including action against school and housing segregation and an increase in the federal minimum wage. King himself described such legislation as an effort to "cash a check" drawn on the promise of emancipation for African Americans. In other words, the speech and its context acted as an instance of deliberative rhetoric to the extent that it demanded concrete judgment and action. On the other hand, King's speech is filled with passages that contribute less obviously to its strictly deliberative purpose: mountains and valleys, darkness and light, and allegorical journeys to redemption. He casts his audience not only as deliberators with the power to effect a needed set of policies, but as crucial agents in an epochal shift that lies just over the horizon. With their help, the corrupted present will be transformed into a dream-like future where, "on the red hills of Georgia, the sons of former slaves and the sons of former slave owners will be able to sit down together at the table of brotherhood" (1990 [1963], 217, 219).

The speech thus functions both as a call to action and as the creation of a shared experience of hope and solidarity. Indeed, its effectiveness may lie in its fusion of the narrow and diffuse instrumentalities characteristic of deliberative rhetoric and preaching, respectively. Or in different terms, one might see it as combining elements of deliberative and epideictic oratory. The latter is an oratory of "display" - both of the speaker's talents and of an object to be praised (or denigrated) - and it shares a good deal with the diffuse instrumentality of preaching. In the Aristotelian tradition, deliberative and epideictic oratory were seen as strictly separate activities, because they aimed at different ends: deliberative oratory "urges us either to do or not to do something," while epideictic oratory "either praises or censures" without otherwise prompting to action (Aristotle 1984, 1358b). In urging the passage of legislation, while simultaneously displaying a future of emancipation, King shows how these ends can be made to work in concert. 
Having considered how each of the three distinctive features of preaching might be transposed into political contexts, we now turn to see how all three are integrated within Frederick Douglass's remarkable speech, "What to the Slave is the Fourth of July?", which he delivered to the Ladies Anti-Slavery Society of Rochester on July $5^{\text {th }}, 1852$. Though other analysts have found a rich variety of influences, virtues, and shortcomings in this text (e.g., Frank 2010; Mills 1998) our focus is narrower: our aim is simply to further illustrate the techniques of identity-oriented discourse we have analyzed, by highlighting how Douglass uses of each of them in this well-known speech.

First, Douglass' unconditionality is on full display in his unflinching condemnation of slavery, which refuses to absolve even his highly sympathetic audience. He scorns the suggestion that he moderate his claims in order to appeal more widely, and mocks the idea of answering slaveholders according to "the rules of logic and argumentation," as if the moral legitimacy of slavery were "a matter beset with great difficulty." He makes no concessions to the perspective of his opponents, preferring to let the moral clarity of his own position speak for itself. At the same time, he excludes no one from his audience as beyond the reach of his arguments. On Douglass's account, slavery is so clearly repugnant to reason and humanity that it would "insult [the] understanding" of his audience to expect anything less than immediate and absolute condemnation from them (1999 [1852], 196). Crucially, his ire here is not reserved for Southern slaveholders or their Northern enablers, but extends even to his hosts, who are already active in the fight against slavery.

Second, the speech is soaked through with appeals to textual and traditional authority. In many cases, these references are biblical, but his appeals to American founding ideals are even more pervasive. In the first section, addressing America's past, Douglass heaps measured but seemingly genuine praise upon its revered founders. And in the final section, looking to the future after his blistering attack on present-day conditions, he even praises the Constitution as a "glorious liberty 
document" - sharply contradicting the abolitionist William Lloyd Garrison's assessment of it as a "covenant with death, and agreement with Hell." Scholars debate whether this break with his former mentor was sincere or primarily strategic, but it is clear that this speech seeks to use the Constitution's authority to encourage transformative shifts in American identity. Drawing on texts and traditions central to that identity, he aims both to convert listeners into committed abolitionists, and to mobilize those already devoted to the cause to pursue it with greater urgency.

Third, Douglass's speech clearly demonstrates an attitude of diffuse instrumentality, as well as many of its associated stylistic tropes. Again, his purpose is not to urge a particular judgment or action upon his audience, but rather a more militant orientation in general. He calls for "scorching irony" rather than "convincing argument," but even this demand is thick with metaphor: "it is not light that is needed, but fire; it is not the gentle shower, but thunder. We need the storm, the whirlwind, and the earthquake." Meanwhile, the speech itself follows a carefully constructed narrative of creation, fall, and redemption — first celebrating the founders' genius, then excoriating the evils of slavery, and then embracing the Constitution as a path towards a future when America's founding promises will be redeemed. As King would do a century later, Douglass places the audience at the inflection point of this narrative - at the cusp of a redemptive conclusion. If only they embrace their historic role, his listeners can become heroic leaders in the brave tradition of the founders, who nobly sided "with the oppressed against the oppressor" (1999 [1852], 196, 190).

As Jason Frank has argued, such factors make Douglass's speech more legible as an attempt at conversion than as an attempt at persuasion. Douglass works not merely to prove a set of claims, but to intervene in a political culture that "renders African Americans incapable of having their claims heard as claims." Before those arguments can have any force for his white listeners, "the demonstration must first convert them into the kind of people who could themselves 
retrospectively authorize such a claim" $(2010,216,212)$. At the most fundamental level, then, it is Douglass's effort to author a receptive audience- to change the kind of people his listeners are - that makes it fruitful to analyze his speech as an example of preaching in politics.

\section{Political evangelizing: promises and challenges}

One reason to examine discourses of conversion and mobilization is simply that they have received less attention than deliberative persuasion. Yet it is especially important to do so now, as the dynamics of identity become increasingly salient. As scholars of polarization in contemporary American politics put it, politics has become our identity (Mason 2018). Partisanship has become so closely bound to social, cultural, and religious markers of identity, in other words, that a shift from one party to another may resemble a religious conversion more than a mere shift of opinion.

Furthermore, some of the most pressing political issues depend heavily on questions of group membership and identification. For example, a common claim about the limits of social democracy holds that generous public services are only sustainable in homogenous political communities. As Carl Melin, a Swedish labor policy analyst, put it, "People are quite open to showing solidarity for people who are like themselves. They don't show solidarity for people who are different" (quoted in Goodman 2019). If "difference" is primarily construed in ethnocultural terms, this suggests that Scandinavian social democracy is unlikely to withstand the pressures of mass migration, and that efforts to build social democracy in more ethnically diverse societies are doomed from the beginning. But such arguments depend on the assumption that categories of "like" and "different" are fixed. The tradition of preaching, by contrast, figures them as fluid. Whether they develop more expansive notions of national belonging or promote the salience of alternative bases of solidarity, proponents of social democracy will likely find themselves in need of identity-oriented discourse. 
To be sure, not all readers will see social democracy as a worthy goal. More generally, it is a commonplace of the rhetorical tradition that any technique is just as susceptible to use for ill as for good. In what remains, then, we set aside the ends of evangelizing political speech, in order to consider its promises and pitfalls as a means of communication in a democracy. As noted at the outset, indeed, it is not our intention to advocate for such discourse, but simply to recognize and grapple with its significance in contemporary political life. Given the lengthy time horizon of identity-oriented discourse modeled on preaching, it is difficult to measure its impact, and we cannot prove that it will be more successful at achieving long-term political change than opinionoriented deliberative rhetoric. Yet there is substantial evidence that the effect of deliberative reasoning is likely to be quite limited, and our analysis suggests that an identity-oriented approach could be more impactful. Perhaps it is unsurprising, then, that what Teresa Bejan $(2015,1113)$ calls "evangelism — more so than deliberation or persuasion — more aptly describes much of what the citizens of modern liberal democracies actually do in the public sphere." As a result, it is imperative to address the normative stakes of identity-oriented discourse more fully.

On the positive side, we noted that preaching on the homiletic model is less prone to pandering than deliberative rhetoric. Its unconditional quality makes preaching less susceptible to the dangers of speech that uncritically echoes listeners' existing prejudices and preconceptions. A public sphere increasingly characterized by preaching is apt to be one with greater room for parrhesia: frank speech, or the practice of making uncomfortable arguments to potentially hostile audiences. If deliberative rhetoric is ultimately founded on appeal to the sensus communis, preaching need not be-and so may open possibilities for more radical change.

Preaching may also be less prone to instrumentalize listeners. As we have noted, the deliberative orator's goal is that the listener render a given judgment. In pursuit of this end, she 
might employ persuasive techniques that, in Kant's words (1951 [1790], 173), "move men in important matters like machines"-poll-tested phrases, for instance, which secure unreflective compliance. She may have ethical or aesthetic reasons not to employ such techniques, of course, but doing so does not contravene her essential purpose: a vote obtained through instrumentalizing means is still a vote. The preacher, by contrast, is in a different situation. Because her goal is mobilization or conversion-involving profound shifts in the listener's self-conceptionsuperficial or perfunctory compliance is insufficient. The preacher wants to win over the listener as an integral person, not as a means to a tick on a ballot. On the homiletic model, at least, preaching that instrumentalizes or objectifies the listener is therefore a self-contradiction.

Evangelizing or "preachy" political discourse has sometimes been criticized for expressing a haughty disrespect for those it aims to convert. Mark Lilla, for instance, has accused "identity liberals" of turning away from the work of political persuasion and instead "delivering sermons to the unwashed from a raised pulpit" $(2018,111-2)$. If our extension of the homiletic account is plausible, however, political preaching can actually demonstrate considerable respect for its audience — by refusing to pander, speaking frankly, and refusing to instrumentalize listeners.

Nevertheless, political preaching also has a number of objectionable qualities. For one, its unconditionality makes it poorly suited to democratic give-and-take. As we observed above, one of the sharpest distinctions between deliberative rhetoric and preaching is that the former generally seeks a point of contact with listeners' pre-existing beliefs, while the latter tends to disdain such accommodation. This disdain is especially troubling for those who value deliberative persuasion as a means of expressing regard for our fellow citizens. In order to establish a rhetorical point of contact, an orator must first engage with listeners as they are, not as she might wish them to be. She must learn about their convictions and dispositions in some detail, and must take their beliefs 
seriously enough to calibrate her message in response. By contrast, recall, the preacher "does not wait to check the climate of the audience" (Craddock 1985, 44). And as defenders of deliberative rhetoric might observe, it is just this process of checking the climate that has the potential to make rhetoric a collaborative, democratic process, in which the audience's existing beliefs and the orator's words exert reciprocal influence on one another (Garsten 2006, 3-4).

Second, the democratic character of preaching may also be limited by its ties to authoritative texts and traditions. As we have seen, even the oldest of traditions can, at times, furnish powerful resources for social change. But these resources are not unlimited. The preacher must work within an inherited system of symbols, examples, and narratives; she cannot start from scratch. Thus, even political preachers who defend oppressed and marginalized groups often find success by calling upon the traditions their audiences accept as authoritative-as with Douglass and the Constitution. While that approach can sometimes be effective, it is troubling that preaching may require the oppressed to pay homage to the symbols of the society responsible for their oppression.

Third, this reliance on external authority may be problematic in another sense: because, as Melvin Rogers $(2015,222)$ puts it, "the logic of authorization seemingly shifts from the people to something that stands outside of them." Political speech based on this sort of external appealwhether to the word of God or to the example of the founders-may be especially conducive to hierarchical, "custodial" (Reed 1999, 17) or even "messianic" (Wilson 1988, 22) politics. However, this need not be the case. As Rogers notes, appeals to external authority may be compatible with democratic politics if they enlist the audience in the work of interpretation. If some preachers demand that their listeners alienate their interpretive judgment, others speak in a way that is "consistent with the spirit of inquiry and investigation" $(2015,227$; see also Shulman 2008 on prophecy as "a political office posing fateful collective decisions to an audience"). 
Finally, even the reduced likelihood that preaching will instrumentalize listeners has a cost. As we argued, the preacher aims to reorient selves, not (just) preferences: preaching is concerned with the listener as a whole person. But we may not always want public notice taken of us as whole persons. We may want, instead, to reserve something of ourselves: to offer votes rather than conversion narratives, to advocate for our interests without having to produce moral inventories as the price of admission to the public sphere. A political culture in which preaching plays an increasingly prominent role will be a more totalizing politics, one which calls us to participate with nothing less than our whole selves. Not everyone will welcome that vision.

\section{Conclusion}

In our view, a great deal of contemporary political discourse is oriented to identity rather than opinion, and thus bears a greater resemblance to religious preaching than the deliberative models long favored by democratic theorists. And as polarization continues to grow, the importance of such political preaching is only likely to grow with it. If political theorists continue to take reasonable deliberation and other forms of persuasive rhetoric as the default models of political discourse, therefore, it seems to us that they will continue to overlook much of what is normatively interesting about real political speech-both in hopeful and in troubling ways. This essay has started to remedy this neglect, turning to the scholarly discipline of homiletics in order to identify the distinct promises and challenges of political preaching.

That said, we have hardly done justice to the complex questions involved, and we close by recommending several areas for future exploration. One is to consider the situational aptness of preaching. Despite their advantages, for instance, preaching's unconditionality and grounding in external authority can threaten the democratic quality of discourse. As a result, democratic citizens should hope that political discourse does not uniformly come to resemble preaching. The tools of 
political theory can help, by distinguishing between situations where an orientation toward identity is appropriate, and those where it is likely to do more harm than good.

A second task would be to "secularize" homiletics' account of the preacher's responsibilities. Homileticians have long known that the preacher's considerable authority as an interpreter of sacred texts and shaper of identities is subject to abuse: there is always the risk of "the minister becoming an autocratic and complacent dominus" (Barth 1991 [1932-33], 20). As such, they have developed accounts of the preacher's responsibility to the congregation, humility before the text, and sense of religious duty as checks on this potential abuse. What might it mean for a political preacher to be checked in the same way? Under what conditions does preaching contribute to "custodial" politics, and under what conditions does it foster democratic conversation?

Finally, political theorists might consider the responsibilities of mutually opposed political preachers, and their adherents, to one another. Here, Bejan's account of "evangelical toleration" is especially relevant. As she argues, a community in which political discourse resembles preaching will not necessarily be an intolerant one. Would-be evangelists may conclude that a fully open and raucous public sphere - equally accessible to the discourse of the "damned" and the "saved"offers the best opportunities for winning converts. And in such a public sphere, "constant evangelical engagement with the damned could perhaps keep us from demonizing them in the way that cloaking oneself in the righteous certainty of the like-minded certainly will" $(2015,1113)$. The theoretical challenges posed by that sort of engagement have more to do with the management of the suspicions arising from mutual, manifold unconditionalities than with the design of ideally reasonable deliberative procedures. We will be better able to respond to those challenges when, as students of political discourse, we begin to see preaching as closer to the rule than the exception. 


\section{Acknowledgments}

For feedback and discussion, the authors are very grateful to Mark Brown, James Patterson, Ali Tranvik, Isak Tranvik, and attendees of the 2019 conference of the Association for Political Theory and the 2019 Braga Colloquium in the History of Moral and Political Philosophy. Thanks, as well, to the Research Group on Constitutional Studies at McGill University, where both authors were fellows during the early stages of work on this article. Finally, the authors would like to thank Jacob T. Levy, the Journal of Politics editorial staff, and several anonymous reviewers.

\section{References}

Achen, Christopher and Larry Bartels. 2016. Democracy for Realists: Why Elections Do Not Produce Responsive Government. Princeton: Princeton University Press.

Allen, Danielle S. 2004. Talking to Strangers: Anxieties of Citizenship since Brown vs. Board of Education. Chicago: University of Chicago Press.

Allen, Donna E. 2013. Toward a Womanist Homiletic: Katie Cannon, Alice Walker and Emancipatory Proclamation. New York: Peter Lang.

Aristotle. 1984. Rhetoric. Trans. W. Rhys Roberts. In Jonathan Barnes, ed., The Complete Works of Aristotle. Vol. 2. Princeton: Princeton University Press, 2152-2269.

Asad, Talal. 2003. Formations of the Secular. Stanford: Stanford University Press.

Bächtiger, André, Markus Spörndli, Marco Steenbergen, and Jürg Steiner. 2007. "Deliberation in Legislatures: Antecedents and Outcomes." In Shawn W. Rosenberg, ed., Can the People

Govern? Deliberation, Participation, and Democracy. New York: Palgrave Macmillan, 82-100.

Barber, Michael and Jeremy Pope. 2019. "Does Party Trump Ideology? Disentangling Party and Ideology in America." American Political Science Review 113 (1): 38-54.

Bartels, Larry M. 2002. "Beyond the Running Tally: Partisan Bias in Political Perceptions." Political Behavior 24 (2): 117-150.

Barth, Karl. (1932-33) 1991. Homiletics. Trans. Geoffrey Bromiley and Donald Daniels. Louisville: Westminster John Knox Press.

Bejan, Teresa M. 2015. “Evangelical Toleration.” Journal of Politics 77 (4): 1103-14.

Bejan, Teresa M. 2017. Mere Civility: Disagreement and the Limits of Toleration. Cambridge: Harvard University Press.

Benhabib, Seyla. 1996. "Toward a Deliberative Model of Democratic Legitimacy.” In Benhabib, ed., Democracy and Difference. New York: Cambridge University Press, 67-94. 
Bercovitch, Sacvan. 1978. The American Jeremiad. Madison: University of Wisconsin Press.

Brewer, Marilynn B. 1991. "The Social Self: On Being the Same and Different at the Same Time.” Personality and Social Psychology Bulletin 17 (5): 475-82.

Brueggemann, Walter. 1993. The Bible and Postmodern Imagination. London: SCM Press.

Burke, Kenneth. 1969. A Rhetoric of Motives. Berkeley: University of California Press.

Buttrick, David. 1987. Homiletic: Moves and Structures. Philadelphia: Fortress Press.

Cohen, Joshua. 1997. "Deliberation and Democratic Legitimacy." In James Bohman and

William Rehg, eds., Deliberative Democracy: Essays on Reason and Politics. Cambridge: MIT Press, 67-91.

Craddock, Fred B. 1985. Preaching. Nashville: Abingdon Press.

Douglass, Frederick. (1852) 1999. "What to the Slave Is the Fourth of July?" In Philip S. Foner, ed., Selected Speeches and Writings. Chicago: Lawrence Hill Books, 188-205.

Elster, Jon. 1986. "The Market and the Forum: Three Varieties of Political Theory.” In Elster and Aanund Hylland, eds., Foundations of Social Choice Theory. New York: Cambridge University Press, 103-132.

Florence, Anna Carter. 2007. Preaching as Testimony. Louisville: Westminster John Knox Press.

Frank, Jason. 2010. Constituent Moments: Enacting the People in Postrevolutionary America. Durham, NC: Duke University Press.

Fry Brown, Teresa. 2003. Weary Throats and New Song: Black Women Proclaiming God's Word. Nashville: Abingdon Press.

Fung, Archon. 2005. "Deliberation before the Revolution: Toward an Ethics of Deliberative Democracy in an Unjust World." Political Theory 33 (3): 397-419.

Garsten, Bryan. 2006. Saving Persuasion: A Defense of Rhetoric and Judgment. Cambridge: Harvard University Press.

Gilbert, Kenyatta R. 2011. The Journey and Promise of African American Preaching. Minneapolis: Fortress Press.

Gilbert, Kenyatta R. 2016. A Pursued Justice: Black Preaching from the Great Migration to Civil Rights. Waco, Texas: Baylor University Press. 
Goodin, Robert E., and Simon J. Niemeyer. 2003. "When Does Deliberation Begin? Internal Reflection versus Public Discussion in Deliberative Democracy." Political Studies 51 (4): 627649.

Goodman, Peter S. 2019. "The Nordic Model May Be the Best Cushion Against Capitalism. Can It Survive Immigration?” New York Times, July 11.

Green, Donald, Bradley Palmquist, and Eric Schickler. 2002. Partisan Hearts and Minds: Political Parties and the Social Identity of Voters. New Haven: Yale University Press.

Greene, Steven. 1999. "Understanding Party Identification: A Social Identity Approach.” Political Psychology 20 (2): 393-403.

Habermas, Jürgen. 1996. Between Facts and Norms. Trans. William Rehg. Cambridge: MIT Press.

Howard, Philip N. 2006. New Media Campaigns and the Managed Citizen. Cambridge: Cambridge University Press.

Huddy, Leonie. 2001. "From Social to Political Identity: A Critical Examination of Social Identity Theory.” Political Psychology 22 (1): 127-56.

Huddy, Leonie, Lilliana Mason, and Lene Aarøe. 2015. "Expressive Partisanship: Campaign Involvement, Political Emotion, and Partisan Identity." American Political Science Review 109 (1): $1-17$.

Iyengar, Shanto, Gaurav Sood, and Yphtach Lelkes. 2012. "Affect, Not Ideology: A Social Identity Perspective on Polarization.” Public Opinion Quarterly 76 (3): 405-31.

Kahan, Dan M. et al. 2007. "Culture and Identity-Protective Cognition: Explaining the White Male Effect in Risk Perception.” Journal of Empirical Legal Studies 4 (3): 465-505.

Kant, Immanuel. (1790) 1951. Critique of Judgment. Trans. J.H. Bernard. New York: Hafner Press.

Kelsey, David H. 1975. The Uses of Scripture in Recent Theology. Philadelphia: Fortress Press.

King, Jr., Martin Luther. "I Have a Dream.” (1963) 1990. In James Washington, ed., A Testament of Hope: The Essential Writings and Speeches. New York: HarperCollins, 217-20.

Klandermans, P. G. 2014. "Identity Politics and Politicized Identities: Identity Processes and the Dynamics of Protest.” Political Psychology 35 (1): 1-22.

Knight, Jack and James Johnson. 1997. "What Sort of Political Equality Does Deliberative Democracy Require.” In Bohman and Rehg, eds., Deliberative Democracy: Essays on Reason and Politics. Cambridge: MIT Press, 279-319. 
Kreiss, Daniel. 2017. "Micro-Targeting, the Quantified Persuasion.” Internet Policy Review 6 (4). policyreview.info/articles/analysis/micro-targeting-quantified-persuasion.

Kunda, Ziva. 1990. "The Case for Motivated Reasoning.” Psychological Bulletin 108 (3): 480498.

Lepoutre, Maxime, 2018. "Rage inside the machine: Defending the place of anger in democratic speech.” Philosophy, Politics, and Economics 17 (4): 398-426

Lilla, Mark. 2018. The Once and Future Liberal: After Identity Politics. New York:

HarperCollins.

Lincoln, Abraham. (1860) 1953. “Cooper Union Address.” In Roy Basler, ed., The Collected

Works of Abraham Lincoln. Vol. 3. Springfield, IL: Abraham Lincoln Association.

Lincoln, Bruce. 2006. Holy Terrors: Thinking about Religion after September 11. 2nd ed. Chicago: University of Chicago Press.

Lischer, Richard. 1988. "Preaching and the Rhetoric of Promise." Word and World 8 (1): 66-79.

Lischer, Richard. 1995. The Preacher King: Martin Luther King, Jr. and the Word that Moved America. New York: Oxford University Press.

Lodge, Milton and Charles Taber. 2013. The Rationalizing Voter. Cambridge: Cambridge University Press.

Long, Thomas G. 2005. The Witness of Preaching. 2nd ed. Louisville: Westminster John Knox Press.

Luskin, Robert C., James S. Fishkin, and Roger Jowell. 2002. "Considered Opinions: Deliberative Polling in Britain.” British Journal of Political Science 32 (3): 455-487.

Mahmood, Saba. 2015. Religious Difference in a Secular Age: A Minority Report. Princeton: Princeton University Press.

Mansbridge, Jane et al. 2010. "The Place of Self-Interest and the Role of Power in Deliberative Democracy." Journal of Political Philosophy 18 (1): 64-100.

Margolis, Michele F. 2018. From Politics to Pews: How Partisanship and the Political Environment Shape Religious Identity. Chicago: University of Chicago Press.

Mason, Lilliana. 2018. Uncivil Agreement: How Politics Became Our Identity. Chicago: University of Chicago Press.

Miller, Perry. 1939. The New England Mind. Cambridge, MA: Harvard University Press. 
Mills, Charles. 1998. "Whose Fourth of July? Frederick Douglass and 'Original Intent." In Mills, ed., Blackness Visible: Essays on Philosophy and Race. Ithaca: Cornell University Press.

Mitchell, Henry H. 1973. "Black Preaching.” Review and Expositor 70 (3): 331-40.

Mitchell, Henry H. 1990. Celebration and Experience in Preaching. Nashville: Abingdon Press.

Mitchell, Henry H. 1997. "African-American Preaching: The Future of a Rich Tradition.” Interpretation 51 (4): 371-83.

Monroe, Kristen, James Hankin, and Renée Bukovchik Van Vechten. 2000. "The Psychological Foundations of Identity Politics.” Annual Review of Political Science 3: 419-47.

Moses, Wilson Jeremiah. 1988. The Golden Age of Black Nationalism, 1850-1925. New York: Oxford University Press.

Murphy, Andrew R. 2009. Prodigal Nation. New York: Oxford University Press.

Nyhan, Brendan, and Jason Reifler. 2010. "When Corrections Fail: The Persistence of Political Misperceptions.” Political Behavior 32 (2): 303-330.

Phillips, Anne. 1995. The Politics of Presence. Oxford: Oxford University Press.

Reed, Adolph. 1999. Stirrings in the Jug: Black Politics in the Post-Segregation Era. Minneapolis: University of Minnesota Press.

Rogers, Melvin L. 2015. "David Walker and the Political Power of the Appeal." Political Theory 43 (2): 208-33.

Sanders, Lynn M. 1997. “Against Deliberation.” Political Theory 25 (3): 347-76

Shapiro, Ian. 1999. "Enough of Deliberation: Politics Is about Interests and Power." In Macedo, ed., Deliberative Politics. New York: Oxford University Press, 28-38.

Shulman, George. 2008. American Prophecy: Race and Redemption in American Political Culture. Minneapolis: University of Minnesota Press.

Strickler, Ryan. 2018. "Deliberate with the Enemy? Polarization, Social Identity, and Attitudes toward Disagreement." Political Research Quarterly 71 (1): 3-18.

Taber, Charles S., and Milton Lodge. 2006. "Motivated Skepticism in the Evaluation of Political Beliefs.” American Journal of Political Science 50 (3): 755-69.

Tajfel, Henri, ed. 1978. Differentiation between Social Groups: Studies in the Social Psychology of Intergroup Relations. London: Academic Press. 
Tajfel, Henri. 1982. Social Identity and Intergroup Relations. Cambridge: Cambridge University Press.

Thiele, Leslie. 2006. The Heart of Judgment: Practical Wisdom, Neuroscience, and Narrative. Cambridge: Cambridge University Press.

Thomas, Frank A. 2016. Introduction to the Practice of African American Preaching. Nashville: Abingdon Press.

Young, Iris Marion. 2000. Inclusion and Democracy. New York: Oxford University Press.

Young, Iris Marion. 2001. "Activist Challenges to Deliberative Democracy." Political Theory 29 (5): 670-90.

Rob Goodman is Assistant Professor of Politics and Public Administration at Ryerson University, Toronto, ON, Canada M5B 2K3.

Samuel Bagg is Postdoctoral Prize Research Fellow in Politics at Nuffield College, Oxford University, Oxford, UK OX1 1NF. 